Review

\title{
Development of Electrochemical Sensors/Biosensors to Detect Natural and Synthetic Compounds Related to Agroalimentary, Environmental and Health Systems in Argentina. A Review of the Last Decade
}

\author{
Adrian M. Granero ${ }^{1, *}$, Héctor Fernández ${ }^{1}$, María A. Zon ${ }^{1}$, Sebastián N. Robledo ${ }^{2}$, Gastón D. Pierini ${ }^{1}{ }^{10}$, \\ Aylen Di Tocco ${ }^{1}$, Roodney A. Carrillo Palomino ${ }^{1}$, Sabrina Maccio ${ }^{1}$, Walter I. Riberi ${ }^{1} \mathbb{D}$ and Fernando J. Arévalo ${ }^{1, *}$ \\ 1 Departamento de Química, Grupo GEANA, Instituto Para el Desarrollo Agroindustrial y de la Salud (IDAS), \\ Facultad de Ciencias Exactas, Físico-Químicas y Naturales, Universidad Nacional de Río Cuarto, Agencia \\ Postal No 3, Río Cuarto 5800, Argentina; hfernandez@exa.unrc.edu.ar (H.F.); azon@exa.unrc.edu.ar (M.A.Z.); \\ gpierini@exa.unrc.edu.ar (G.D.P.); aditocco@exa.unrc.edu.ar (A.D.T.); rcarrillo@exa.unrc.edu.ar (R.A.C.P.); \\ smaccio@exa.unrc.edu.ar (S.M.); iriberi@exa.unrc.edu.ar (W.I.R.) \\ 2 Departamento de Tecnología Química, Grupo GEANA, Instituto Para el Desarrollo Agroindustrial y de la \\ Salud (IDAS), Facultad de Ingeniería, Universidad Nacional de Río Cuarto, Agencia Postal No 3 , \\ Río Cuarto 5800, Argentina; srobledo@ing.unrc.edu.ar \\ check for
updates \\ * Correspondence: agranero@exa.unrc.edu.ar (A.M.G.); farevalo@exa.unrc.edu.ar (F.J.A.)
}

Citation: Granero, A.M.; Fernández, H.; Zon, M.A.; Robledo, S.N.; Pierini, G.D.; Di Tocco, A.; Carrillo Palomino, R.A.; Maccio, S.; Riberi, W.I.; Arévalo, F.J. Development of Electrochemical Sensors/Biosensors to Detect Natural and Synthetic Compounds Related to Agroalimentary, Environmental and Health Systems in Argentina. A Review of the Last Decade. Chemosensors 2021, 9, 294. https://doi.org/10.3390/ chemosensors 9110294

Academic Editors: Anirban Paul and Giuseppe Maruccio

Received: 16 September 2021

Accepted: 12 October 2021

Published: 20 October 2021

Publisher's Note: MDPI stays neutral with regard to jurisdictional claims in published maps and institutional affiliations.

Copyright: (c) 2021 by the authors. Licensee MDPI, Basel, Switzerland. This article is an open access article distributed under the terms and conditions of the Creative Commons Attribution (CC BY) license (https:// creativecommons.org/licenses/by/ $4.0 /)$.

\begin{abstract}
Electrochemical sensors and biosensors are analytical tools, which are in continuous development with the aim of generating new analytical devices which are more reliable, cheaper, faster, sensitive, selective, and robust than others. In matrices related to agroalimentary, environmental, or health systems, natural or synthetic compounds occur which fulfil specific roles; some of them (such as mycotoxins or herbicides) may possess harmful properties, and others (such as antioxidants) beneficial ones. This imposes a challenge to develop new tools and analytical methodologies for their detection and quantification. This review summarises different aspects related to the development of electrochemical sensors and biosensors carried out in Argentina in the last ten years for application in agroalimentary, environmental, and health fields. The discussion focuses on the construction and development of electroanalytical methodologies for the determination of mycotoxins, herbicides, and natural and synthetic antioxidants. Studies based on the use of different electrode materials modified with micro/nanostructures, functional groups, and biomolecules, complemented by the use of chemometric tools, are explored. Results of the latest reports from research groups in Argentina are presented. The main goals are highlighted.
\end{abstract}

Keywords: sensors; biosensors; immunosensors; electrochemistry; agro-food; environment; health

\section{Introduction}

The increase in the world population has led to the development of a large number of substances of interest related to the main demands of the population, particularly in the food and health industries and those derived from them. Synthetic and natural antioxidants, mycotoxins, herbicides, and other compounds related to health are a representative group of these compounds. Thus, the development of new control analytical tools that allow the determination of different compounds associated with this situation is of great interest to the scientific and international communities.

The diet of the world population has become a topic of interest for governments and for the scientific community. It has been shown that the intake of an adequate diet rich in nutrients and biologically active compounds is related to a better quality of life and to a notable decrease in cardiovascular, tumour, and neurodegenerative diseases, among others [1-4]. A family of compounds which must be present in a balanced diet is antioxidants (vitamins, carotenoids, minerals, phenols, and polyphenols) [5,6]. Antioxidants are the 
main components responsible for antioxidant activity in an organism and are present in a wide variety of fruits and vegetables [7-11]. Numerous studies have shown that antioxidants can help prevent diseases by reducing oxidative stress in the human body [12,13]. Phenolic compounds represent a large group of plant metabolites and are part of both human and animal diets. Phenolic compounds are a heterogeneous family of chemical compounds such as phenolic acids, flavonoids, tannins, stilbenes, etc. Their relevance is related to their organoleptic properties, such as colour, astringency, taste, and bitterness [14,15]. They have pharmacological properties such as cardio protective activity, lipid-lowering activity by direct scavenging of radicals, gastrointestinal protection, antioxidant activity, inhibition effects on expression of heat shock proteins, anti-inflammatory and analgesic activity, antimicrobial activity, anti-osteoporotic effects, etc. [16].

On the other hand, it is possible to find contaminants such as mycotoxins in commodities and manufactured food. They are produced by a wide variety of filamentous fungi. The main fungi are Aspergillus, Penicillium, Fusarium, Byssochlamys, Stachybotrys, Trichoderma, Alternaria, Chaetomium, and Paecilomyces [17-19]. In the 1980s, the Food and Agriculture Organization of the United Nations (FAO) indicated that toxicogenic fungi mainly affect approximately $25 \%$ of crops [20]. However, due to the combination of the improved sensitivity of analytical methods and climate change, the occurrence above detectable levels reaches $60-80 \%$ of mycotoxin contamination of food crops [21]. This point is relevant for countries whose economic activities are based on the production of cereals, seeds, oilseeds, fruits and vegetables, nuts, raisins, and spices, and manufactured products such as fruit juice, wine, and bakery products [22-24]. The ingestion of food contaminated with mycotoxins can produce moderate and severe health risks (Table 1) [25]. Based on the cancer risk for human health produced by mycotoxins, the International Agency for Research on Cancer (IARC) classified them into different categories [26].

Table 1. IARC classification and effects produced by different mycotoxins. See the abbreviation list at the end of the article.

\begin{tabular}{cl}
\hline Mycotoxins & \multicolumn{1}{c}{ Effects } \\
\hline ZEA & $\begin{array}{l}\text { It produces reproductive disorders, estrogens, abortions and sterility, and hepatotoxic, } \\
\text { immunotoxic, and hemato-toxic effects. }\end{array}$ \\
\hline ZEN & It can produce breast cancer, with strong and prolonged endocrine-disruptive effects in humans. \\
\hline MON & $\begin{array}{l}\text { Is an oxidation inhibitor of intermediates in the tricarboxylic acid cycle, causing respiratory } \\
\text { diseases and myocardial degeneration. }\end{array}$ \\
\hline CIT & It produces nephrotoxic, kidney disease in monogastrics, body tremors, immunosuppression, etc. \\
\hline OTA & It is a powerful nephrotoxic, teratogenic, and immunosuppressive agent. \\
\hline ZER & It is a ZEA derivative and is considered an endocrine-disrupting compound. \\
\hline PAT & It produces neurotoxic, immunological, mutagenic, genotoxic, and teratogenic problems. \\
\hline STE & $\begin{array}{l}\text { Aflatoxin B1 precursor. It has carcinogenic effects related to gastric, hepatic, and esophageal } \\
\text { carcinomas. }\end{array}$ \\
\hline
\end{tabular}

* Group IIA: probably carcinogenic to humans; there is limited evidence in humans but sufficient in animals. Group IIB: possibly carcinogenic; the evidence in humans is limited, and there is not enough evidence with experimental animals. Group III: not classifiable as a human carcinogen and cannot be included in another group.

Food contamination with mycotoxins has led several countries and organisations to adopt control of regulations such as the Codex Alimentarius Commission (dependent on the United Nations), which establishes regulatory methods worldwide [27].

In connection with the intensive farming methods used in the production of food commodities, herbicides also appear as dangerous contaminants [28,29]. Herbicides are used to control and eliminate unwanted weeds and grasses from crops. However, their intensive use generates environmental problems given that a high herbicide contamination of soils, waters, and manufactured foods is dangerous [30-32]. Thus, the FAO [33], European Union [34], and Mercosur [35] have legislated tolerable amounts of herbicides in different foods and beverages to ensure food quality. Herbicides of the triazine family are widely applied in agricultural products, and their presence in foods or drinking water can cause harmful health effects such as malformations, cancers, and others [36]. Therefore, 
the development of sensitive and accurate methods for the detection and quantification of triazine herbicides is very important.

In this sense, electrochemical sensors/biosensors are presented as powerful analytical tools for the detection and quantification of these compounds related to agroalimentary, environmental, and health systems. The possibility to combine sensitive electrochemical techniques and the versatility of electrodes and/or modified electrodes with nanomaterials and/or biomolecules allows the development of very sensitive and selective devices [37,38]. On the other hand, their performance can be improved using chemometric tools [39]. This review aims to show on results of the development of electrochemical sensors/biosensors produced in Argentina in the last decade for the detection and quantification of compounds related to agroalimentary, environmental, and health systems. A description of the main advantages and applications is performed.

\section{Natural and Synthetic Antioxidants, and Others Phenolic/Polyphenolic Compounds}

Electrochemical sensors or biosensors are an excellent alternative to determine the content of total polyphenols in different samples. In addition, several analytical methods combining chemometric tools with electrochemical techniques have gained great attention to determine different analytes in complex matrices by using first-and second-order data, which allow to obtain a considerable improvement of the performance of a given electrochemical sensor.

\subsection{Electrochemical Sensor}

Eguílaz et al. developed an interesting method for the determination of total polyphenolic content in tea extracts [40]. The electrochemical sensor was based on a GCE modified with a SWCNT dispersion covalently bonding to polytyrosine (Polytyr) (SWCNTPolytyr/GCE). Gallic acid (GA) was used as reference analyte. The calibration curve showed a concentration linear range (CLR) from $5.0 \times 10^{-7}$ to $1.7 \times 10^{-4} \mathrm{M}$, a sensitivity of $(0.518 \pm 0.005) \mathrm{A} \mathrm{M}^{-1} \mathrm{~cm}^{-2}$, and a limit of detection (LOD) of $8.8 \times 10^{-9} \mathrm{M}$.

Gutiérrez et al. reported the detection of quercetin (QER) using a GCE modified with MWCNT dispersed in polyethylenimine (PEI) and poly(acrylic acid) (PAA) [41]. Adsorptive stripping square wave voltammetry was used for the detection of QER using an accumulation time of $1.0 \mathrm{~min}$ at open circuit potential. The electrochemical sensors showed a LOD of $0.2 \times 10^{-6} \mathrm{M}$. Table 2 shows the analytical parameters for each modification of the electrode surface (with MWCNT dispersed in PEI or PAA). The proposed methodology was used to quantify QER in presence of an excess of rutin (RUT) in onion samples.

Table 2. Analytical parameters obtained for PEI-MWCNT/GCE and PAA-MWCNT/GCE sensors for the quantification of QER by adsorptive stripping with SWV detection. See the abbreviation list at the end of the article.

\begin{tabular}{cccc}
\hline Dispersion Used & CLR (M) & Sensitivity $\left(\mu \mathbf{A ~ M ~ M}^{-\mathbf{1}}\right)$ & LOD (M) \\
\hline PEI-MWCNT & $8.0 \times 10^{-7}$ to $7.0 \times 10^{-6}$ & $(2.5 \pm 0.1) \times 10^{6}$ & $8.9 \times 10^{-8}$ \\
PAA-MWCNT & $1.0 \times 10^{-7}$ to $5.0 \times 10^{-6}$ & $(8.7 \pm 0.3) \times 10^{6}$ & $7.5 \times 10^{-7}$ \\
\hline
\end{tabular}

Tesio et al. developed an interesting electrochemical sensor for the determination of the flavonoid luteolin (LUT) in peanut hull samples [42]. The sensor was based on a GCE modified with a MWCNT/PEI dispersion (MWCNT-PEI/GCE). LUT was oxidised on MWCNT-PEI/GCE by quasi-reversible surface oxidation showing a defined oxidation peak centred at $0.680 \mathrm{~V}$. The electrochemical sensor showed a CLR from $2.4 \times 10^{-3}$ to $1.75 \times 10^{-6} \mathrm{M}$, a sensitivity of $124 \mathrm{~A} \mathrm{M}^{-1}$ and a LOD of $5.0 \times 10^{-10} \mathrm{M}$. The limit of quantification (LOQ) was $1.5 \times 10^{-9} \mathrm{M}$. The reproducibility of MWCNT-PEI/GCE, evaluated from the sensitivity of calibration curves using five modified electrodes, shows a relative standard deviation (RSD) of $8.0 \%$. In addition, repeatability assays yielded a RSD of 7.3\%. The performance of electrochemical sensor was compared with HPLC measurements, being both values in very good agreement. In addition, Tesio et al. developed an electroanalytical 
method to quantify LUT and RUT simultaneously, which are present in a pharmaceutical formulation [43]. This method was based on the use of a modified GCE with MWCNT/PEI dispersion applying adsorptive stripping square wave voltammetry as the electrochemical technique. LUT and RUT are oxidised to similar potential values producing an overlapping signal. Therefore, the electrochemical signals were processed using artificial neural networks (ANN). Values of $92.6 \pm 0.4$ and $92 \pm 1 \mathrm{mg}$ per tablet were determined by the ANN methodology for LUT and RUT, respectively, showing a difference of $7.4 \%$ and $8.0 \%$ for LUT and RUT, respectively, according to values declared by the manufacturer. A very simple extraction step of LUT and RUT of the sample was performed before applying the electrochemical measurements.

On the other hand, Gomez et al. have developed a method for the determination of QER in yellow, red, and green onions [44]. The method was based on natural deep eutectics solvents (NADES) electrolyte combined with unmodified CSPE. The method showed a wide CLR from $0.016 \times 10^{-6}$ to $17 \times 10^{-6} \mathrm{M}$, and a LOD and a LOQ of $7.9 \times 10^{-9} \mathrm{M}$ and $2.6 \times 10^{-8} \mathrm{M}$, respectively. The QER content in onions determined by this method was compared with those obtained by HPLC. A relative error $<9.5 \%$ was obtained showing a good agreement between both methodologies.

Tonello et al. have simultaneously determined eugenol (EU), thymol (Ty), and carvacrol (CAR) in honey samples using square wave voltammetry and ANN [45]. A GCE was used as a working electrode. The square wave voltammograms showed signals overlapping. Therefore, a supervised ANN was adopted for problem modelling. Recovery percentages (\%R) obtained for EU, Ty, and CAR was varied between $87 \%$ and 104\%, except for two samples whose values were $136 \%$ and $72 \%$. The results obtained indicate a satisfactory applicability of the proposed method. This method is simple, fast, and accurate, and does not require a previous step of sample preparation.

Robledo et al. have developed a sensor for the determination of total phenolic monoterpenes in essential oils [46]. The sensor was based on a GCE using linear sweep voltammetry for Ty and CAR quantification. The standard addition method was not necessary, because the slopes obtained from the calibration curves in the pure reaction medium and those obtained from the standard additions method for each essential oil were not significantly different. A CLR from $8.5 \times 10^{-5}$ to $1.3 \times 10^{-3} \mathrm{M}$, and $7.9 \times 10^{-5}$ to $1.2 \times 10^{-3} \mathrm{M}$ were obtained for Ty and CAR, respectively. In addition, LOD and LOQ of $7.9 \times 10^{-5} \mathrm{M}$ and $2.2 \times 10^{-4} \mathrm{M}$ for Ty, and $8.6 \times 10^{-5} \mathrm{M}$ and $2.5 \times 10^{-4} \mathrm{M}$ for CAR were obtained. The proposed method is simple, quick, and inexpensive.

Hoyos-Arbeláez et al. have proposed an electrochemical sensor to determine mangiferin (MG) based on a modified GCE with different types of carbonaceous materials dispersed in water or Nafion ${ }^{\circledR}$ [47]. The carbonaceous materials used were GO, MWCNT, and SWCNT. When the GCE was modified with carbonaceous nanomaterial/Nafion dispersions, the fouling electrode was avoided and an improvement in the diffusion of MG to the electrode surface was reached. Table 3 shows the LOD, LOQ, and coefficient of determination $\left(\mathrm{R}^{2}\right)$ values obtained for each carbonaceous material/GCE used to quantify MG. The GO/Nafion/GCE configuration was the best option for MG determination. These results suggest that GO/Nafion/GCE is a good analytical tool to quantify MG.

Table 3. Calibration parameters obtained for MG determination by different carbonaceous materials used in the modification of the GCE. See the abbreviation list at the end of the article.

\begin{tabular}{cccc}
\hline Modified Electrode & LOD (M) & LOQ (M) & $\mathbf{R}^{\mathbf{2}}$ \\
\hline GO/Nafion/GCE & $6.3 \times 10^{-8}$ & $2.1 \times 10^{-7}$ & 0.9987 \\
MWCNT/Nafion/GCE & $1.9 \times 10^{-7}$ & $6.3 \times 10^{-7}$ & 0.9965 \\
SWCNT/Nafion/GCE & $4.8 \times 10^{-7}$ & $1.6 \times 10^{-6}$ & 0.9942 \\
\hline
\end{tabular}

Pierini et al. have developed a new and interesting methodology to detect capsaicin (CAP) from to increase in the electroactive area of CSPE [48]. The methodology was based on electrochemical intercalation process in which an electrochemical reaction uses 
an electrolyte as a conducting medium and as an intercalation source, followed by steps of exfoliation and heating/drying by microwave irradiation (called EDI-SPEs). The increase in the electroactive area improved the sensibility for CAP determination in Tabasco sauce samples. A CLR from $5 \times 10^{-6}$ to $100 \times 10^{-6} \mathrm{M}$ and LOD of $0.36 \times 10^{-6} \mathrm{M}$ were obtained. Recovery assays were employed in order to validate the methodology. An average recovery of $95 \%$ was obtained, indicating the good performance of the proposed electrochemical sensor.

Additionally, Pierini et al. developed a novel electrochemical method to determine taxifolin (TX) in peanut oil samples based on CSPE and adsorptive stripping square wave voltammetry [49]. The accumulation parameters (accumulation time and potential) were optimised by using a composite central design (CCD). The $\mathrm{pH}$, supporting electrolyte, scan rate, and different possible interferents such as daidzein (DZ), QER, t-Res, and CA at two concentration levels $\left(1 \times 10^{-6}\right.$ and $\left.10 \times 10^{-6} \mathrm{M}\right)$ were studied. A CLR from $5 \times 10^{-8}$ to $1 \times 10^{-6} \mathrm{M}$, and a LOD of $2.1 \times 10^{-8} \mathrm{M}$ were obtained. A reproducibility of $4.2 \%$ was obtained for the TX determination. The proposed method shows several advantages for the TX determination with respect to the other electrochemical methods such as a low reagent consumption ( $75 \mu \mathrm{L}$ per sample), absence of electrode cleaning step, possibility of decentralised analysis, and the use a simple and disposable unmodified electrode.

With respect to synthetic antioxidants, there are many reports within the literature. Robledo et al. reported a qualitative and quantitative analysis of different mixtures of synthetic antioxidants in edible oils using square wave voltammetry and Pt band ultramicroelectrode (UME) [50]. The methodology was based on the comparison of voltammetric signals obtained when different aliquots of tetrabutylammonium hydroxide (TBAOH) were added to the sample, allowing a qualitative differentiation due to the different acidbase properties of antioxidants. Binary mixtures of tert-butyl hydroxyanisole (BHA) + tert-butyl hydroxytoluene (BHT), BHA + propyl gallate (PG), BHA + tert-butyl hydroquinone (TBHQ), and BHT + PG as well as the ternary mixtures BHA + TBHQ + BHT and $\mathrm{BHA}+\mathrm{BHT}+\mathrm{PG}$ were resolved after different extraction steps with acetonitrile. Square wave voltammograms recorded in the absence and in the presence of different aliquots of TBAOH allowed the differentiation of the antioxidants added.

Robledo et al. proposed a simple electroanalytical method to determine tocopherols and BHT in edible vegetable oils based on a carbon fibre (CF) disk, and Pt band UME by square wave voltammetry [51]. Tocopherol determinations were performed in benzene/ethanol (1:2) + $0.1 \mathrm{M} \mathrm{H}_{2} \mathrm{SO}_{4}+$ oil samples at a disk CF UME. BHT was determined in acetonitrile at a $\mathrm{Pt}$ band UME after performing its extraction from the oil sample with acetonitrile. The \%R determined by the standard additions method was in the range from $92 \%$ to $102 \%$. Antioxidant concentrations calculated were in good agreement with those values declared by the manufacturers.

Robledo et al. studied electrochemical oxidation of tocopherols at CF disk UME in benzene/ethanol $(2: 1)+0.1 \mathrm{M} \mathrm{H}_{2} \mathrm{SO}_{4}$ media using square wave voltammetry [52]. As anodic signals of tocopherol were overlapped, the ANNs method was used as model to quantify tocopherols in edible oil samples. The \%R was between 94 and $99 \%$. In addition, differences between 1.4 and $6.8 \%$ were found for the total tocopherol content in edible oil samples and the vitamin E content declared by the manufacturer.

Second- and higher-order modelling can exploit the second-order advantage, and selectively determine the analyte even in the presence of non-modelled constituents. One of the most powerful chemometric methods which allow for solving this situation is the multivariate curve resolution-alternating least squares (MCR-ALS). However, only a few reports combine electrochemical techniques and multiway chemometric methods for quantitative purposes. Pierini et al. have developed a novel analytical method using second-order modelling on cyclic voltammograms based on multivariate curve resolutionalternating least squares (MCR-ALS) [53]. CAR was determined in the presence of Ty in oregano essential oils, without sample pre-treatment. The heterogeneous reaction of CAR is a process governed by diffusion. To generate second-order data, the scan rate $(v)$ 
was used as a second instrumental mode and cyclic voltammograms at different $v$ were acquired for a single sample. The LOD and LOQ were estimated using the MCR-ALS. They were $6.27 \times 10^{-5} \mathrm{M}$ and $1.90 \times 10^{-4} \mathrm{M}$, respectively. The developed methodology was successfully implemented to quantify CAR in oregano essential oil samples.

Many scientific efforts are focused on the development of reliable, fast, sensitive methods of two compounds of singular interest in the health system: uric acid (UA) and dopamine (DA). UA is the major hydrophilic anti-oxidative component present in the blood. Abnormal UA levels indicate signs of gout, kidney, and cardiovascular-related diseases. Gutiérrez et al. have developed an electrochemical sensor for UA quantification in the presence of ascorbic acid (AA) [54]. The sensor was based on GCE modified with MWCNT/PEI dispersion. The electrochemical sensor showed a CLR from $0.5 \times 10^{-6}$ to $5 \times 10^{-5} \mathrm{M}$, and a sensitivity of $(0.72 \pm 0.02) \mathrm{A} \mathrm{M}^{-1}$. The LOD and LOQ were $1 \times 10^{-7} \mathrm{M}$ and $3 \times 10^{-7} \mathrm{M}$, respectively. The $\mathrm{R} \%$ values between 98 and $105 \%$ were obtained for the determination of UA in urine samples without pre-treatment. DA is the most abundant neurotransmitter in human brains. It is secreted by the brain, and it has a great influence on the operation of the central nervous, hormonal, and cardiovascular systems [55]. An improper amount of DA relates to a variety of health issues. Gutiérrez et al. have developed an electrochemical sensor for the determination of DA in urine samples [56]. The electrochemical sensor was prepared by modifying of a GCE with polylysine (PLys)functionalised with SWCNT (SWCNT-PLys/GCE). UA and AA were used as potential interferents in the determination of DA. The SWCNT-PLys/GCE sensor showed a CLR from $1.0 \times 10^{-7}$ to $2.0 \times 10^{-6} \mathrm{M}$, and a sensitivity of $12.6 \mathrm{~A} \mathrm{M}^{-1}$. The LOD and LOQ were $16 \times 10^{-9} \mathrm{M}$ and $48 \times 10^{-9} \mathrm{M}$, respectively. The sensor was used successfully for the determination of DA in urine samples diluted in phosphate-buffered solution. A \% $\mathrm{R}$ of $(96 \pm 9) \%$ was obtained.

Granero et al. have developed an analytical method for simultaneous determination of AA, UA and DA [57]. The analytical method was based on a model of three-way calibration using second-order data generated from the combination of forward (oxidation) and reverse (reduction) currents from squarewave voltammetry. A GCE modified with a dispersion of electrochemically reduced GO (RGO/GCE) was used. Recovery studies were performed in order to validate the proposed method using lyophilized samples of human serum. The \%R of the spiked samples were between 92.4 and 120\% (for AA, UA, and DA), showing that the electrochemical sensor is an interesting tool for clinical uses.

The development of analytical methods based on electrochemical sensors has many advantages over traditional methods. However, some aspects such as the possibility of passivation of the electrode surface, the overlapping of signals between analytes and interferents molecules, as well as the effects of the matrix, should be considered in the construction of electrochemical sensors. At present, there are many possibilities to build electrodes with different shapes and sizes, that is, UME, disk, band, interdigitated, etc., from the use of different materials. The use of new materials of regular or nanometric size, or an adequate combination of them, allows for solving these problems successfully, generating an increase in the development of new electroanalytical methods.

Furthermore, the recent increase in the use of both different chemometric tools and electroanalytical methods was effective in solving problems of signal overlap or matrix effects.

\subsection{Electrochemical Biosensors}

Granero et al. have developed an amperometric enzymatic biosensor to determine total polyphenolic content in wine and tea samples [58]. The biosensor was based on Brassica napus hairy roots peroxidase (PBHR) + ferrocene $\left(\mathrm{FC}_{\mathrm{C}}\right)$ and MWCNT embedded in a mineral oil (MWCNT + MO) placed inside the cavity of a paste electrode. The PBHR-Fc-MWCNT + MO/electrode was covered externally with a dialysis membrane (cut-off molecular weight 100). The t-resveratrol (t-Res) and caffeic acid (CA) were used as reference standard compounds. The calibration plots for $\mathrm{t}-\mathrm{Res}$ and CA showed CLRs from $2.2 \times 10^{-7}$ to $2.28 \times 10^{-4} \mathrm{M}$, and from $3.3 \times 10^{-7}$ to $3.83 \times 10^{-4} \mathrm{M}$ for $\mathrm{t}-\operatorname{Res}(\mathrm{r}=0.9997)$ and 
CA $(r=0.9999)$, respectively. The lowest concentration value measured was $0.1 \times 10^{-6} \mathrm{M}$ for both t-Res and CA. This biosensor is an excellent tool to determine polyphenols in wine and tea samples.

On the other hand, Mohtar et al. developed an electrochemical biosensor for the determination of the total polyphenolic content in propolis samples [59]. The biosensor was based on the enzyme lacase (Lac) immobilised on AuNPs deposited in a CSPE modified with polypyrrole (Ppy) (Ppy/Lac/AuNPs/CSPE). The precision of the electrochemical biosensor was tested with standards of CA of $5 \times 10^{-6}, 20 \times 10^{-6}$, and $40 \times 10^{-6} \mathrm{M}$ concentrations. The polyphenols assay showed RSD values for within-assay and betweenassay experiments below $4.3 \%$ and $6.6 \%$, respectively.

Recently, López et al. have developed an amperometric biosensor to determine EUG in dental samples [60]. The biosensor was constructed by immobilising a conjugate of adamantane (ADA) and soybean peroxidase enzyme (SPE) (forming ADA-SPE) on a GCE modified with a chemically reduced graphene oxide (CRGO) and $\beta$-cyclodextrin ( $\beta C D s)$ $(\beta C D s-C R G O)$. In addition, AuNPs were electrogenerated on the surface of the electrode. Thus, the CRGO- $\beta C D$ s / ADA-SPE/AuNPs/GCE biosensor was obtained (Figure 1). The enzymatic biosensor showed a CLR from $1.3 \times 10^{-8} \mathrm{M}$ to $1 \times 10^{-5} \mathrm{M}$, a sensitivity of $(5.3 \pm 0.3) \times 10^{-3} \mathrm{~A} \mathrm{M}^{-1}$, and a LOD of $4 \times 10^{-9} \mathrm{M}$. The LOQ was $1.3 \times 10^{-8} \mathrm{M}$. The reproducibility, expressed as RSD, was $5 \%$ and $8 \%$ for intra- and interday assays, respectively. The repeatability, expressed as RSD, was $3 \%$, and it was obtained when the same biosensor was used. In addition, a stability of at least fifteen days was obtained. On the other hand, the CRGO- $\beta$ CDs/ADA-SPE/AuNPs/GCE biosensor was used to determine EUG in samples of products of dental use. The \%Rs between 94 and $108 \%$ were obtained, showing the good performance of the biosensor for the determination of EUG.
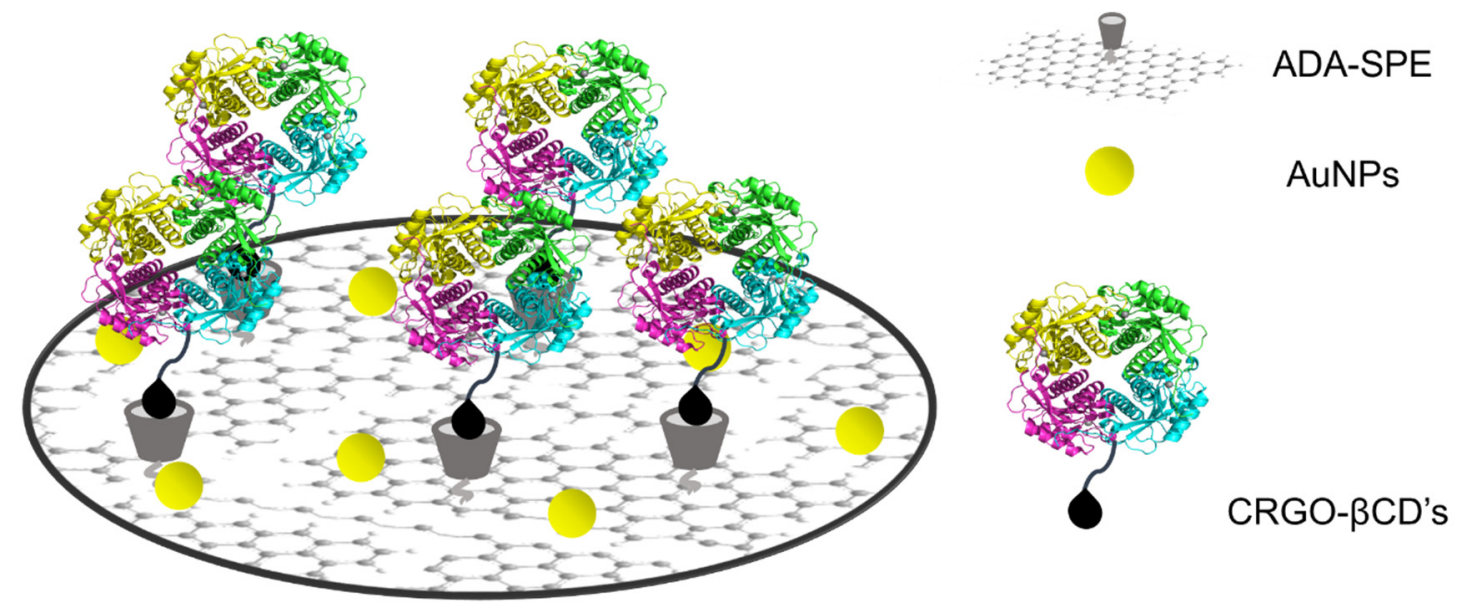

Figure 1. Schematic representation of CRGO- $\beta C D$ 's/ADA-SPE/AuNPs/GCE biosensor for determination of EUG in products of dental use.

Table 4 shows other electrochemical sensors/biosensors to detect and quantify natural and synthetic antioxidants developed in Argentina.

As described above, electrochemical biosensors have numerous advantages over other analytical tools. The most important advantage is selectivity and sensitivity. First, due to the fact that biological sensors take advantage of a good selectivity of biomolecules for a certain substrate. This inherent selectivity of biological molecules makes it be possible to eliminate or reduce the problems of the damaging effects of interferents or the effects of the matrix of the sample analysed. Second, electroanalytical techniques are among the most sensitive. Therefore, the effective combination of biomolecules and electrochemical techniques allows obtaining very valuable analytical tools. 
Table 4. Electrochemical sensors/biosensor for natural and synthetic antioxidants detection developed in Argentina in the last 10 years. See the abbreviation list at the end of the article.

\begin{tabular}{|c|c|c|c|c|}
\hline Electrochemical Device & Analyte & LOD & Sample & Ref. \\
\hline$\beta-\mathrm{CD} / \mathrm{MWCNT} / \mathrm{GCE}$ & Mangiferin & $8.64 \times 10^{-7} \mathrm{M}$ & - & [61] \\
\hline GCE & Propofol & $5.5 \times 10^{-7} \mathrm{M}$ & Water & {$[62]$} \\
\hline Polyhis/MWCNT/GCE & $\begin{array}{c}\text { AA } \\
\text { Paracetamol }\end{array}$ & $\begin{array}{l}7.6 \times 10^{-7} \mathrm{M} \\
3.2 \times 10^{-8} \mathrm{M}\end{array}$ & $\begin{array}{l}\text { Pharmaceutical } \\
\text { formulations }\end{array}$ & [63] \\
\hline $\begin{array}{c}\text { GrPE } \\
\text { PPO-GrPE } \\
\mathrm{NAD}^{+} / \mathrm{ADH} / \mathrm{GrPE}\end{array}$ & $\begin{array}{c}\text { DA } \\
\text { Catechin } \\
\text { Ethanol }\end{array}$ & $\begin{array}{c}4 \times 10^{-7} \mathrm{M} \\
8.2 \times 10^{-8} \mathrm{M} \\
56 \times 10^{-6} \mathrm{M}\end{array}$ & $\begin{array}{c}\text { Urine } \\
\text { Tea bag } \\
\text { Alcoholic beverages }\end{array}$ & [64] \\
\hline GCE & Tryptamine & $8 \times 10^{-10} \mathrm{M}$ & $\begin{array}{c}\text { Bananas, tomatoes, } \\
\text { cheese, and cold } \\
\text { meats }\end{array}$ & [65] \\
\hline EPPGE & $\begin{array}{l}\mathrm{Hx} \\
\mathrm{Xa} \\
\mathrm{UA}\end{array}$ & $\begin{array}{l}8 \times 10^{-8} \mathrm{M} \\
6 \times 10^{-8} \mathrm{M} \\
3 \times 10^{-8} \mathrm{M}\end{array}$ & Fish & [66] \\
\hline
\end{tabular}

Polyhis: polyhistidine. $\beta$-CD: $\beta$-cyclodextrin. GrPe: graphene paste electrode. PPO-GrPE: graphene paste electrode modified with polyphenol oxidase. $\mathrm{NAD}^{+} / \mathrm{ADH} / \mathrm{GrPE}$ : graphene paste electrode modified with alcohol dehydrogenase and cofactor $\mathrm{NAD}^{+}$EPPGE: edge plane pyrolytic graphite electrode.

Therefore, a very important and crucial step in the construction of electrochemical biosensors is the immobilisation of biological molecules and the subsequent storage of the sensor, which allows achieving high selectivity and a longer lifetime. However, the effective immobilisation of biomolecules on the electrode surface, and the long-term stability of these sensors is a problem which is not completely resolved. Researchers are making great efforts to solve this problem.

\section{Mycotoxins}

Different research groups in Argentina have performed studies related to the development of electrochemical sensors, enzymatic biosensors, and immunosensors for the detection of mycotoxins. Our group produced a large part of them. In this section, a detailed description of electrochemical sensors/enzymatic biosensors/immunosensors is made.

\subsection{Ochratoxin $A$}

Ochratoxin A (OTA) is one of the most important mycotoxins due to the risk it presents to human and animals health. OTA is a mycotoxin produced by several species of the Aspergillus and Penicillium fungi and can be present in different foods such as grains and manufactured products (pasta, purees, fruit-based beverages such as wine, apple juice, cider, etc.) [25]. In the last ten years, more than 1600 articles have been published on different methodologies to quantify OTA in different samples. However, the development of electrochemical sensors/biosensors for the detection of OTA, using optical, electrochemical, piezoelectric, etc. transductors is continuous.

Perrotta et al., from Universidad Nacional de Río Cuarto, developed an electrochemical sensor for the detection and quantification of OTA in red wines based on the electrooxidation of OTA on a gold electrode in $20 \%$ acetonitrile $+80 \% \mathrm{pH} 4.00$ buffer solution [67]. The sensor was constructed by a cysteamine self-assembled monolayer on gold electrodes. The cysteamine self-assembled monolayer allowed a greater sensitivity for the detection of OTA due to an interaction between the mycotoxin and the thiol monolayer through Van der Waals, resonance, and electrostatic forces and hydrogen bonding. In this work, squarewave voltammetry was used as electrochemical technique. OTA was oxidised by quasi-reversible electrochemical oxidation of its electro-oxidation product. The sensor showed a \% $\mathrm{R}$ of $117 \%$ and a $\% C V$ of $27 \%$ at a level of $0.020 \mathrm{ng} \mathrm{mL}^{-1}$. The LOD and LOQ were $4 \mathrm{pg} \mathrm{mL}^{-1}$ and $12 \mathrm{pg} \mathrm{mL}^{-1}$, respectively. OTA was determined in red wines, where extraction of 
OTA based on double liquid partition L I I L was necessary. The electrochemical sensor was validated with the Association of Official Analytical Chemists (AOAC) 2001.01 official method [68]. A comparison by regression lines between methodologies showed a slope of $(0.892 \pm 0.038)$, indicating the good performance of the electrochemical sensor.

Fernández-Baldo et al. developed a competitive indirect immunoassay method based on 3-aminopropyl-modified magnetic nanoparticles (MNPs) as a platform to immobilise the anti-OTA antibody, incorporated into a microfluidic system for the quantification of OTA in apples (Red Delicious) contaminated with Aspergillus ochraceus [69]. The LOD obtained was $0.05 \mathrm{mg} \mathrm{kg}^{-1}$. Moreover, the intra and inter-assay coefficients of variation were below $6.5 \%$.

Perrotta et al. have developed an electrochemical immunosensor for OTA determination in red wine samples based on a competitive immunoassay using OTA labelled with HRP [23]. The electrochemical immunosensor was formed by magnetics beads modified with $G$ protein, which allowed the immobilisation of anti-OTA monoclonal antibody on CSPE (Figure 2). The benzoquinone generated in the enzymatic cyclic was reduced on CSPE by square wave voltammetry. The electrochemical immunosensor showed a very good performance. A LOD of $4 \mathrm{pg} \mathrm{mL}^{-1}$ was obtained, being one of the lowest values found in the literature. OTA was determined in red wines with a \%R between 92 and 110\%. The electrochemical immunosensor was validated with the official method of AOAC [68]. A comparison by regression lines between methodologies showed a slope $=0.95 \pm 0.04$.

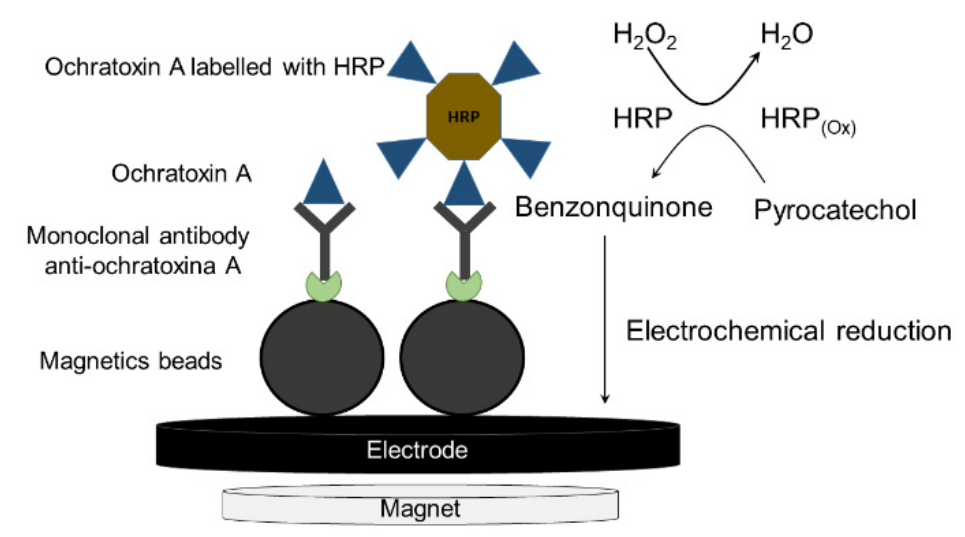

Figure 2. Schematic representation of electrochemical immunosensor for OTA determination in red wine samples.

\subsection{Moniliformin}

Moliformin (MON) is an emergent mycotoxin and is found in cereals such as maize, rice, barley, wheat, oats, rye, and triticale [70]. MON is produced by a large number of Fusarium species [25]. Our group was a pioneer in the development of an electrochemical sensor for the quantification of MON in corn samples [71]. A complete study on the electrochemical oxidation of MON by cyclic and squarewave voltammetries in acetonitrile was performed. A complex electro-oxidation mechanism formed by weak adsorption of the mycotoxin at the GCE and the presence of chemical reactions coupled to the initial charge transfer reaction was proposed. All thermodynamic and kinetics parameters were calculated. On the other hand, squarewave voltammetry was used to perform the quantitative determination of $\mathrm{MON}$, where a LOD of $1 \times 10^{-11} \mathrm{M}$ was found in pure solvent.

Later, Díaz Toro et al. developed a sensitive electrochemical sensor for the MON quantification in corn samples based on the electrochemical oxidation of MON at cysteamine self-assembled monolayers/gold electrodes [72]. A LOD of $8.3 \times 10^{-10} \mathrm{M}(0.1 \mathrm{ppb})$ and a RDS\% less than $4 \%$ were obtained. The performance of the electrochemical sensor was compared with the HPLC method. A very good agreement was obtained, showing the good performance of the electrochemical sensor. MON extraction was performed from the corn sample prior to electrochemical and HPLC measurements. The MON extraction was 
carried out from a solution of acetonitrile: water (84:16). The extract was then evaporated and dissolved in methanol. This solution was introduced in a strong anion exchange column. Finally, MON was eluted as a MON-tetrabutylammonium ion pair [72].

\subsection{Patulin}

Patulin (PAT) is a mycotoxin produced, principally, by fungi of Penicillium, Aspergillus, and Byssochlamys. PAT is found in a wide variety of foods, such as wheat, nuts, apples, pears, figs, strawberries, mangoes, oranges, apricots, grapes, bananas, peaches, currants, cherries, pineapples, plums, blueberries, tomatoes, and cheeses [73]. In addition, PAT is found in apple and pear manufactured products such as juices, purees, ciders, concentrates, and compotes [74]. Our group studied the electro-reduction of PAT at GCE in acetonitrile by cyclic and square wave voltammetries, and controlled potential bulk electrolysis [75]. A methodology for quantification of PAT in fresh and commercial apple juices was developed. Calibration curves obtained from solutions of the commercial reagent and commercial apple juices were linear in the concentration range from $3.0 \times 10^{-7}$ to $2.2 \times 10^{-5} \mathrm{M}$. A LOD of $3 \times 10^{-7} \mathrm{M}(45 \mathrm{ppb})$, and a $\% \mathrm{R}$ of $84 \%$ was obtained for commercial apple juices [75].

On the other hand, Riberi et al. have developed an electrochemical immunosensor to quantify PAT in apple juice [24]. Since PAT is a small molecule and its labelling with an enzyme is difficult, an non-competitive electrochemical immunoassay was performed. This was based on the measurement of the formation of an immunocomplex between the PAT and an anti-PAT polyclonal antibody immobilised on CSPE modified with GO (Figure 3). Electrochemical impedance spectroscopy was used as the analytical technique. The LOD and the concentration of PAT to obtain $50 \%$ inhibition $\left(\mathrm{IC}_{50}\right)$ were $9.8 \mathrm{pg} \mathrm{mL}-1$ and $360 \mathrm{pg} \mathrm{mL}^{-1}$, respectively. In addition, a \% of $86 \%$ was obtained.

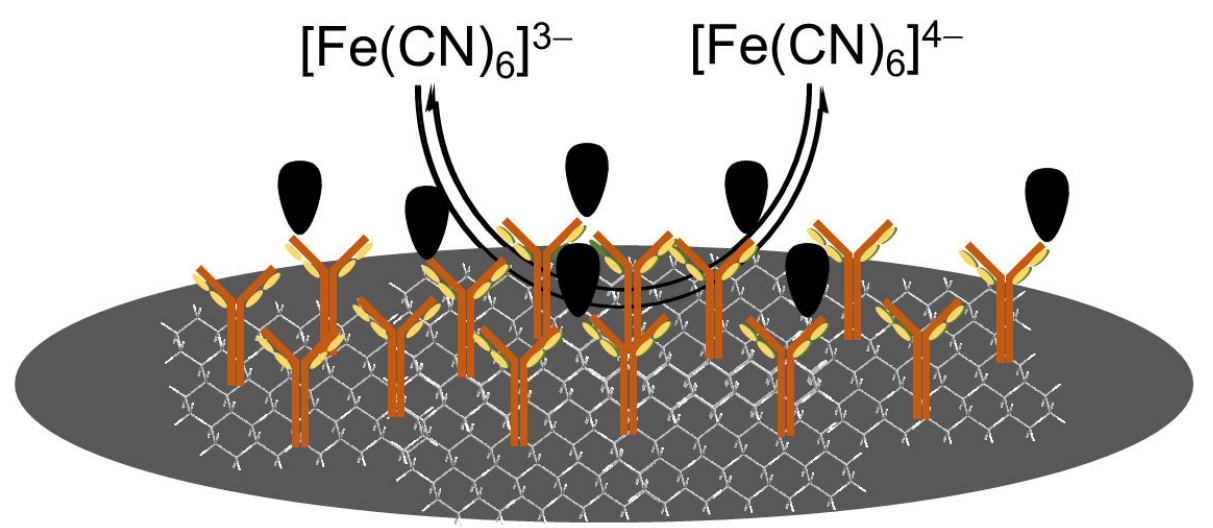

Glassy carbon electrode modified with graphene oxide

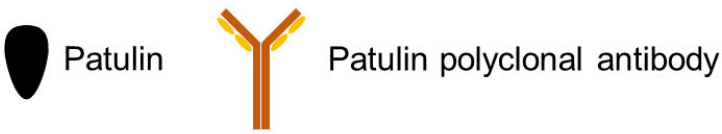

Figure 3. Schematic representation of electrochemical immunosensor for PAT detection in apple juice samples.

\subsection{Citrinin}

Citrinin (CIT) is a secondary metabolite produced by fungi of the Aspergillus Monascus and Penicillium genera, especially P. citrinum, P. verruscosum, and P. expansum [25]. CIT is considered an emerging mycotoxin; therefore, there are few works related to the development of electrochemical sensors/immunosensors for the detection of CIT. Zachetti et al. developed an amperometric biosensor for the quantification of CIT in rice samples [76]. The biosensor was based on a mixture of MWCNT, mineral oil, HRP, and ferrocene (Fc) inserted in an inert tube, covered with a dialysis membrane, forming the MWCNT-HRP-Fc biosensor. CIT is a co-substrate for HRP. Therefore, in the presence of CIT, an increase in 
the reduction current of the ferrocinium ion was observed. The electrochemical biosensor showed a very good performance. A LOD of $0.25 \times 10^{-9} \mathrm{M}$, and a reproducibility and repeatability of $7 \%$ and $3 \%$, respectively, were obtained.

\subsection{Sterigmatocystin}

Sterigmatocystin (STE) is a precursor mycotoxin of aflatoxin $\mathrm{B}_{1}$. STE can be present in different commodities such as peanut, nut trees, cotton, etc. Therefore, early detection of STE will potentially prevent the occurrence of aflatoxin $B_{1}$ in food samples [25]. Díaz Nieto et al. have developed a novel third-generation enzymatic biosensor for the determination of STE in corn samples [77]. The biosensor was based on a composite of chemically reduced GO (CRGO)/SPE deposited on CGE. The electrochemical biosensor showed a LOD of $2.3 \times 10^{-9} \mathrm{M}$, and a CLR from $6.9 \times 10^{-9}$ to $5.0 \times 10^{-7} \mathrm{M}$. The performance of biosensor was analysed in corn samples spiked with STE. A \% R of 96.5\% was obtained. The STE concentration determined using the biosensor was in very good agreement with that determined by HPLC.

Other electrochemical immunosensors to detect and quantify mycotoxins developed in Argentina are listed in Table 5.

Table 5. Electrochemical immunosensors for mycotoxin detection developed in Argentina in the last 10 years. See the abbreviation list at the end of the article.

\begin{tabular}{|c|c|c|c|c|}
\hline Electrochemical Device & Mycotoxin & Sample & LOD & Ref. \\
\hline Immunosensor & OTA & Grape & $0.02 \mathrm{~g} \mathrm{~kg}^{-1}$ & [78] \\
\hline Immunosensor & ZEA & Corn & $0.77 \mathrm{pg} \mathrm{mL}^{-1}$ & [79] \\
\hline Immunosensor & ZEA & Feed stuffs & $0.41 \mu \mathrm{g} \mathrm{kg}^{-1}$ & [80] \\
\hline Immunosensor & ZEA & Corn & $0.15 \mathrm{pg} \mathrm{mL}^{-1}$ & [81] \\
\hline Immunosensor & ZEA & Amaranthus cruentus seed & $0.57 \mathrm{ng} \mathrm{mL}^{-1}$ & [82] \\
\hline Immunosensor & CIT & Rice & $0.1 \mathrm{ng} \mathrm{mL}^{-1}$ & [83] \\
\hline Immunosensor & ZER & Bovine urine & $0.01 \mathrm{ng} \mathrm{mL}^{-1}$ & [84] \\
\hline Immunosensor & ZEN & Bovine urine & $16 \mathrm{pg} \mathrm{mL}^{-1}$ & [85] \\
\hline
\end{tabular}

\section{Herbicides}

There is interest in the development of new reliable analytical tools for the detection of herbicides, which are potentially harmful agents for human and animal health, particularly when herbicides contaminate water sources. This section describes the most relevant electrochemical immunosensors developed in Argentina for the detection of herbicides.

\subsection{Molinate}

Molinate (MO) is a moderately toxic herbicide used in flooded rice fields to treat unwanted weeds. Its drainage towards rivers and lakes generates a growing concern. We have developed two electrochemical immunosensors using phage particles. First, in 2012, a magneto-electrochemical immunosensor based on a competitive immunoassay was developed [86]. The anti-MO monoclonal antibody was immobilised on G proteinmodified magnetic particles retained on a CSPE using a high field magnet. The phage particles have bearing peptides that mimic the MO that compete with the herbicide. An anti-phage monoclonal HRP-labelled antibody was used to recognise the event as an enzymatic substrate and co-substrate were used: $\mathrm{H}_{2} \mathrm{O}_{2}$ and pyrocatechol, respectively. The electrochemical immunosensor showed a CLR from $0.73 \times 10^{-2}$ to $10 \mathrm{ng} \mathrm{mL}^{-1}$, and a LOD $4.4 \mathrm{pg} \mathrm{mL}^{-1}$. The electrochemical immunosensor was used to quantify $\mathrm{MO}$ in river water samples, showing a \%R lower than $110 \%$ and $\%$ VC lower than $6 \%$.

In 2021, Di Tocco et al. developed an electrochemical immunosensor based on phage particles bearing a peptide which specifically recognises the $\mathrm{MO} /$ monoclonal antibody antiMO immunocomplex [87]. The phage was labelled with CdS/3-mercaptopropionic acid stabilised nanocrystal. The electrochemical immunosensor was based on a non-competitive immunoassay. A GCE was modified with a polymeric film formed by electro-oxidation 
of $p$-nitroaniline. Then, the residual nitro group of polymeric film was electrochemically reduced to form the amine group, allowing covalent binding with the antibody (Figure 4). Anodic stripping squarewave voltammetry was used to detect $\mathrm{Cd}^{2+}$ release from the nanocrystal. A LOD of $15.4 \mathrm{pg} \mathrm{mL}^{-1}$, and a \%R close to $100 \%$ were obtained.

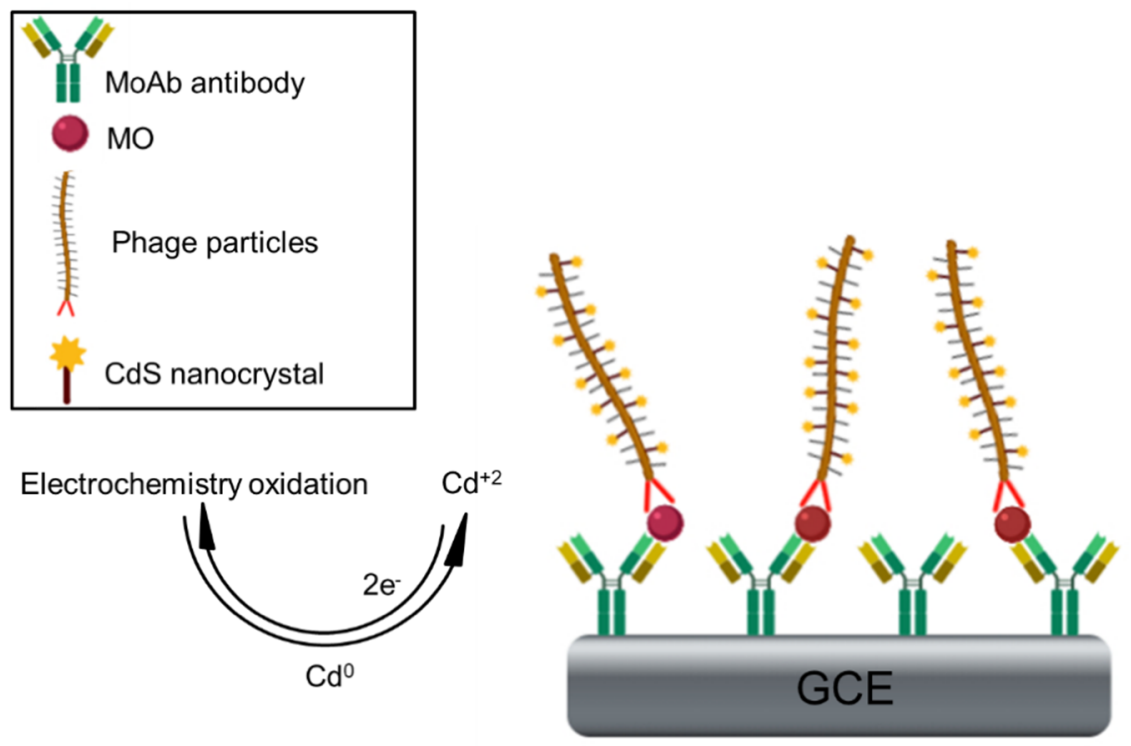

Figure 4. Schematic representation of electrochemical immunosensor for MON detection based on phage particles labelled with CdS nanoparticles.

\subsection{Atrazine}

González Techera et al. have developed an electrochemical immunosensor to detect atrazine (AT), which combines the advantages of magneto-electrochemical immunosensors with the improved sensitivity and direct proportional signal of non-competitive immunoassays [88]. This was based on the use of recombinant M13 phage particles bearing a peptide, which specifically recognises the immunocomplex of AT with an anti-AT monoclonal antibody. The electrochemical immunosensor reaches a LOD of $0.2 \mathrm{pg} \mathrm{mL}^{-1}$, and was successfully used to assay undiluted river water samples without pre-treatment and obtaining excellent recoveries. Other electrochemical sensors/biosensors to detect other herbicides developed in Argentina are listed in Table 6.

The electrochemical immunosensors are considered as a powerful tool for the rapid, selective, sensitive, and low-cost detection of many substances, where a synergic effect between the electrochemical techniques and the antibodies' activity is reached. Very sensitive and selective electrochemical immunosensors have been and continue to be developed, which are in continuous competition with reference techniques such as the chromatographic ones, particularly HPLC. At present, there are challenges to incorporate new types of bioreceptors, such as genetically modified nanobodies and antibodies with an outstanding affinity capacity, which allow to improve the specificity of traditional antibodies and thus develop more selective and sensitive electrochemical immunosensors, with versatile detections. However, it is necessary to achieve more stable electrochemical immunosensors, which allow their manufacture and commercialisation. This point involves effective and stable forms to immobilise the antibody on the electrode surface, allowing the least loss of antibody activity. 
Table 6. Electrochemical sensors/biosensors for herbicides detection developed in Argentina in the last 10 years. See the abbreviation list at the end of the article.

\begin{tabular}{|c|c|c|c|c|}
\hline Electrochemical Device & Herbicide & Sample & LOD & Ref. \\
\hline Bismuth film/GCE & Atrazine & River water & $130 \mathrm{ng} \mathrm{mL}^{-1}$ & [89] \\
\hline Antimony film/GCE & 4,6-dinitro-o-cresol & River water & $221.9 \mathrm{ng} \mathrm{mL}^{-1}$ & [90] \\
\hline GCE electroactivated & Amitraz & Honey & $55.7 \mathrm{ng} \mathrm{mL}^{-1}$ & [91] \\
\hline MB-DNA-MWCNT/AuNPs/Chit/GCE & 4-nonylphenol & - & $0.77 \mathrm{ng} \mathrm{mL}^{-1}$ & [92] \\
\hline CuNPs/CMK-8-CH/SPCE & Glyphosate & River water & $0.09 \mathrm{ng} \mathrm{mL}^{-1}$ & [93] \\
\hline HRP-GEC-E & Glyphosate & $\begin{array}{c}\text { Underground and } \\
\text { surface sources of } \\
\text { water }\end{array}$ & $45 \mathrm{ng} \mathrm{L}^{-1}$ & [94] \\
\hline
\end{tabular}

MB: methylene blue. DNA: deoxyribonucleic acid. Chit: chitosan. CuNPs: copper nanoparticles. CMK-8-CH: mesoporous carbon dispersed in chitosan. GEC-E graphite epoxy compound electrode.

\section{Conclusions}

Argentina's economic activity is fundamentally associated with agriculture and its manufactured products, mainly food. To comply with the legislation of International Organisations (i.e., MERCOSUR, European Community, FAO, etc.), it is necessary to study and develop analytical methodologies which allow for ensuring the required quality parameters. Thus, the Argentina scientific community is in line with the rest of the world in the development of new electroanalytical methodologies, which compete with the methodologies imposed by different international organisations to monitor the quality of different commodities. The aim of this review is to show electrochemical sensor/biosensors which are more sensitive and reliable than official methodologies, which are based on mainly chromatographic techniques, developed in Argentina.

This review highlights the efforts made in the last 10 years by different researchers from Argentina to develop new electroanalytical tools for the detection of a group of substances that have transversal relevance at a global level, which are related to agroalimentary, environmental, and health systems in Argentina. The focus is centred on natural and synthetic antioxidants, phenolic compounds, neurotransmitters, mycotoxins, and herbicides.

The goal of electrochemical tools is the adequate combination of the very sensitive electrochemical techniques with the possibility to develop a highly selective electrode. Very sensitive and selective electrochemical immunosensors are being developed, which are in continuous competition with reference techniques such as HPLC. High sensitivity and selectivity can be achieved with these devices. With respect to the electrode surface, it is necessary to analyse two aspects: first, the electrode material to be used, its dimensions, and the modifications that can be performed. Currently, the electrodes are becoming smaller, tending to miniaturisation, with the advantage of using a lesser amount of reagents and solvents. On the other hand, the use of screen-printed electrodes is increasingly common given their low costs and versatility, opening the possibility of generating portable and disposable transducers. With the discovery of new nanomaterials, there are many alternatives to design new sensors. In addition, these modified electrodes are presented as new platforms which allow for improving the sensitivity and selectivity of electrochemical sensors. In this sense, the use of different carbonaceous materials to modify electrode surfaces is still active and showing great advantages. Second, the development of biosensors using biomolecules such as enzymes and antibodies shows great advantages such as selectivity and sensibility. Currently, stable fragments of enzymes and antibodies (nanobodies) as well as peptides expressed in phages are beginning to be used as alternatives that improve the performance of the resulting biosensors in terms of selectivity, sensitivity, and stability over the time.

Therefore, electrochemical sensors/biosensors are interesting tools to detect and quantify different molecules in complex samples. The possibility of working with naked or modified electrodes with nanomaterials and/or biomolecules is only restricted by the imagination. On the other hand, the use of chemometric tools is useful to solve complex 
responses, especially when analysing voltammograms presents an overlapping sample and interfering currents.

The final goal is to achieve the development of reliable, reproducible, and stable electrochemical sensors/biosensors for the detection of substances of interest, and their practical application.

One of the most important challenges facing the development of electrochemical sensors and/or biosensors is to achieve their commercial use. For this, it is necessary not only to improve the communication between the academic/scientific community and the industrial sector, but there should also be more personnel trained in the use of electroanalytical methods.

The impact of new technologies for the manufacture of suitable and more economically accessible equipment, together with the generation of new materials and the use of chemometric tools, means that the development of electrochemical sensors and/or biosensors will continue to grow in the coming years.

Funding: Agencia Nacional de Promoción Científica y Tecnológica (FONCYT) (PICT 0975/2018 y 1580/2018), Secretaría de Ciencia y Técnica (SECyT) (PPI 2020-2022, Res. Rec. 083/2020) from Universidad Nacional de Río Cuarto.

Institutional Review Board Statement: Not applicable.

Informed Consent Statement: Not applicable.

Acknowledgments: Financial supports from the Agencia Nacional de Promoción Científica y Tecnológica (FONCYT) (PICT 0975/2018 y 1580/2018), Secretaría de Ciencia y Técnica (SECyT) (PPI 2020-2022, Res. Rec. 083/2020) from Universidad Nacional de Río Cuarto are gratefully acknowledged. A. Di Tocco, R. Carrillo Palomino and S. Maccio thank to CONICET for doctoral fellowships.

Conflicts of Interest: The authors declare no conflict of interest.

\section{Abbreviations}

Electrodes and Materials
Carbon fibre
Carbon screen-printed electrode
Glassy carbon electrode
Graphene
Graphene oxide
Gold nanoparticles
Multi-walled carbon nanotube
Single-walled carbon nanotube
Ultra-microelectrode
Phenolic compounds
Ascorbic acid
Caffeic acid
Capsaicin
Carvacrol
Daidzein
Dopamine
Eugenol
Gallic acid
Hypoxanthine
Luteolin
Mangiferin
Propyl gallate
Quercetin

\begin{tabular}{|c|c|c|}
\hline & Herbicides and Enzymes & \\
\hline $\mathrm{CF}$ & Atrazine & AT \\
\hline CSPE & Molinate & $\mathrm{MO}$ \\
\hline GCE & Horseradish Peroxidase & HRP \\
\hline $\mathrm{Gr}$ & Laccase enzyme & Lac \\
\hline GO & Polyphenol oxidase & $\mathrm{PPO}$ \\
\hline AuNPs & Soybean peroxidase enzyme & SPE \\
\hline MWCNT & Mycotoxins & \\
\hline SWCNT & Zearalenona & ZEA \\
\hline \multirow[t]{2}{*}{ UME } & $\alpha$-Zearalanol & ZEN \\
\hline & Moniliformin & $\mathrm{MON}$ \\
\hline AA & Citrinin & CIT \\
\hline CA & Ochratoxin A & OTA \\
\hline CAP & Zeranol & ZER \\
\hline CAR & Patulin & PAT \\
\hline $\mathrm{DZ}$ & Sterigmatocystin & STE \\
\hline DA & Analytical parameters and others & \\
\hline EUG & Limit of detection & LOD \\
\hline GA & Limit of quantification & LOQ \\
\hline $\mathrm{Hx}$ & Concentration linear range & CLR \\
\hline LUT & Relative standard deviation & RSD \\
\hline MG & Recovery percentage & $\% \mathrm{R}$ \\
\hline PG & Coefficient of variation percentage & $\% \mathrm{CV}$ \\
\hline QER & Artificial neural networks & ANNs \\
\hline
\end{tabular}




$\begin{array}{ll}\text { Rutin } & \text { RUT } \\ \text { Taxifolin } & \text { TX } \\ \text { Tert-butyl hydroquinone } & \text { TBHQ } \\ \text { Tert-butyl hydroxyanisole } & \text { BHA } \\ \text { Tert-butyl hydroxytoluene } & \text { BHT } \\ \text { Thymol } & \text { Ty } \\ \text { t-Resveratrol } & \text { t-Res } \\ \text { Uric acid } & \text { UA } \\ \text { Xanthine } & \text { Xa }\end{array}$

\section{References}

1. Pap, N.; Fidelis, M.; Azevedo, L.; Araujo Vieira do Carmo, M.; Wang, D.; Mocan, A.; Penha Rodrigues Pereira, E.; Xavier-Santos, D.; Sant'Ana, A.S.; Yang, B.; et al. Berry polyphenols and human health: Evidence of antioxidant, anti-inflammatory, microbiota modulation, and cell-protecting effects. Curr. Opin. Food Sci. 2021, 42, 167-186. [CrossRef]

2. Duttaroy, A.K. Chapter 14, Polyphenols and their antioxidant and nonantioxidant effects in health and disease. In EvidenceBased Nutrition and Clinical Evidence of Bioactive Foods in Human Health and Disease; Academic Press: New York, NY, USA, 2021; pp. 191-206.

3. Pisoschi, A.M.; Pop, A.; Iordache, F.; Stanca, L.; Predoi, G.; Serban, A.I. Oxidative stress mitigation by antioxidants-An overview on their chemistry and influences on health status. Eur. J. Med. Chem. 2021, 209, 112891. [CrossRef] [PubMed]

4. Singh, B.; Singh, J.P.; Kaur, A.; Singh, N. Phenolic composition, antioxidant potential and health benefits of citrus peel. Food Res. Int. 2020, 132, 109114. [CrossRef] [PubMed]

5. Tuberoso, C.I.G.; Boban, M.; Bifulco, E.; Budimir, D.; Pirisi, F.M. Antioxidant capacity and vasodilatory properties of Mediterranean food: The case of Cannonau wine, myrtle berries liqueur and strawberry-tree honey. Food Chem. 2013, 140, 686-691. [CrossRef] [PubMed]

6. Oroian, M.; Escriche, I. Antioxidants: Characterization, natural sources, extraction and analysis. Food Res. Int. 2015, 74, 10-36. [CrossRef] [PubMed]

7. Ajila, C.M.; Prasada Rao, U.J.S. Mango peel dietary fibre: Composition and associated bound phenolics. J. Funct. Foods 2013, 5, 444-450. [CrossRef]

8. Du, Y.; Li, X.; Xiong, X.; Cai, X.; Ren, X.; Kong, Q. An investigation on polyphenol composition and content in skin of grape (Vitis vinifera L. cv. Hutai No. 8) fruit during ripening by UHPLC-MS ${ }^{2}$ technology combined with multivariate statistical analysis. Food Biosci. 2021, 43, 101276. [CrossRef]

9. Legua, P.; Forner-Giner, M.A.; Nuncio-Jáuregui, N.; Hernández, F. Polyphenolic compounds, anthocyanins and antioxidant activity of nineteen pomegranate fruits: A rich source of bioactive compounds. J. Funct. Foods 2016, 23, 628-636. [CrossRef]

10. Bravo, K.; Alzate, F.; Osorio, E. Fruits of selected wild and cultivated Andean plants as sources of potential compounds with antioxidant and anti-aging activity. Ind. Crops Prod. 2016, 85, 341-352. [CrossRef]

11. Carlsen, M.H.; Halvorsen, B.L.; Holte, K.; Bøhn, S.K.; Dragland, S.; Sampson, L.; Willey, C.; Senoo, H.; Umezono, Y.; Sanada, C.; et al. The total antioxidant content of more than 3100 foods, beverages, spices, herbs and supplements used worldwide. Nutr. J. 2010, 3, 1-11. [CrossRef]

12. Chan, C.; Ren-You, G.; Nagendra, S.; Harold, C. Polyphenols from selected dietary spices and medicinal herbs differentially affect common food-borne pathogenic bacteria and lactic acid bacteria. Food Chem. 2018, 92, 437-443. [CrossRef]

13. Pizzino, G.; Irrera, N.; Cucinotta, M.; Pallio, G.; Mannino, F.; Arcoraci, V.; Squadrito, F.; Altavilla, D.; Bitto, A. Oxidative Stress: Harms and Benefits for Human Health. Oxid. Med. Cell Longev. 2017, 2017, 8416763. [CrossRef]

14. Shahidi, F.; Naczk, M. Phenolics in food and nutraceuticals: Sources. In Applications and Health Effects; CRC Press: Boca Raton, FL, USA, 2004.

15. Stark, T.; Bareuther, S.; Hofmann, T. Sensory-guided decomposition of roasted cocoa nibs (Theobroma cacao) and structure determination of taste-active polyphenols. J. Agric. Food Chem. 2005, 53, 5407-5418. [CrossRef]

16. Narayana, K.R.; Reddy, M.S.; Chaluvadi, M.R.; Krishna, D.R. Bioflavonoids classification, pharmacological, biochemical effects and therapeutic potential. Indian J. Pharm. 2001, 33, 2-16.

17. Whitaker, T.B.; Slate, A.B.; Doko, M.B.; Maestroni, B.M.; Cannavan, A. (Eds.) Sampling Procedures to Detect Mycotoxins in Agricultural Commodities; Springer: Dordrecht, The Netherlands, 2010.

18. Bianchini, A.; Bullerman, L.B. Mycotoxins I Classification. In Encyclopedia of Food Microbiology; Batt, C.A., Tortorello, M.L., Eds.; Academic Press: Oxford, UK, 2014; pp. 854-861.

19. Sharma, A.; Pillai, M.R.A.; Gautam, S.; Hajare, S.N. Mycotoxins Immunological techniques for detection and analysis. In Encyclopedia of Food Microbiology; Batt, C.A., Tortorello, M.L., Eds.; Academic Press: Oxford, UK, 2014; pp. 869-879.

20. Waśkiewicz, A. Mycotoxins I Natural occurrence of mycotoxins in food. In Encyclopedia of Food Microbiology; Batt, C.A., Tortorello, M.L., Eds.; Academic Press: Oxford, UK, 2014; pp. 880-886.

21. Eskola, M.; Kos, G.; Elliott, C.T.; Hajšlová, J.; Mayar, S.; Krska, R. Worldwide contamination of food-crops with mycotoxins: Validity of the widely cited 'FAO estimate' of 25\%. Crit. Rev. Food Sci. Nutr. 2020, 60, 2773-2789. [CrossRef] 
22. Fernández, H.; Arévalo, F.J.; Granero, A.M.; Robledo, S.N.; Díaz Nieto, C.H.; Riberi, W.I.; Zon, M.A. Electrochemical biosensors for the determination of toxic substances related to food safety developed in South America: Mycotoxins and herbicides. Chemosensors 2017, 5, 23. [CrossRef]

23. Perrotta, P.R.; Arévalo, F.J.; Vettorazzi, N.R.; Zón, M.A.; Fernández, H. Development of a very sensitive electrochemical magneto immunosensor for the direct determination of ochratoxin A in red wine. Sens. Actuators B Chem. 2012, 162, 327-333. [CrossRef]

24. Riberi, W.I.; Zon, M.A.; Fernández, H.; Arévalo, F.J. Impedimetric immunosensor to determine patulin in apple juices using a glassy carbon electrode modified with graphene oxide. Microchem. J. 2020, 158, 105192. [CrossRef]

25. Soriano del Castillo, J.M. Micotoxinas en Alimentos; Díaz de Santos: Valencia, Spain, 2007. (In Spanish)

26. International Agency for Research on Cancer (IARC). Mycotoxins and human health. In Mycotoxin Exposure and Human Cancer Risk: A Systematic Review of Epidemiological Studies; IARC: Lyon, France, 2020; Available online: https://www.iarc.who.int/ (accessed on 1 September 2021).

27. Cheli, F.; Campagnoli, A.; Pinotti, L.; Dell'Orto, V. Rapid methods as analytical tools for food and feed contaminant evaluation: Methodological implications for mycotoxin analysis in cereals. In Food Production-Approaches, Challenges and Tasks; Aladjadjiyan, A., Ed.; InTech: Rijeka, Croatia, 2011; pp. 185-204.

28. Monteiro de Castro Lima, J.A.; Labanowski, J.; Camotti Bastos, M.; Zanella, R.; Prestes, O.D.; Rosa de Vargas, J.P.; Mondamert, L.; Granado, E.; Tiecher, T.; Zafar, M.; et al. "Modern agriculture" transfers many pesticides to watercourses: A case study of a representative rural catchment of southern Brazil. Environ. Sci. Pollut. Res. 2020, 27, 10581-10598. [CrossRef] [PubMed]

29. Agost, L.; Velázquez, G.A. Peri-urban pesticide contamination risk index. Ecol. Indic. 2020, 114, 106338. [CrossRef]

30. Marvin, H.J.P.; Bouzembrak, Y. A system approach towards prediction of food safety hazards: Impact of climate and agrichemical use on the occurrence of food safety hazards. Agric. Syst. 2020, 178, 102760. [CrossRef]

31. Ankley, G.T.; Berninger, J.P.; Blackwell, B.R.; Cavallin, J.E.; Collette, T.W.; Ekman, D.R.; Fay, K.A.; Feifarek, D.J.; Jensen, K.M.; Kahl, M.D.; et al. Pathway-Based Approaches for Assessing Biological Hazards of Complex Mixtures of Contaminants: A Case Study in the Maumee River. Environ. Toxicol. Chem. 2020, 40, 1098-1122. [CrossRef]

32. Xie, Y.; Wang, M.; Chen, X.; Wang, S.; Han, D.; Han, Y.; Yan, H. 3-Aminophenol-glyoxylic acid resin for the determination of triazine herbicides in tomatoes. Anal. Chim. Acta 2019, 1061, 122-133. [CrossRef]

33. Available online: http://www.fao.org/about/en/ (accessed on 1 September 2021).

34. Available online: https:/ / europa.eu/european-union/index_es (accessed on 1 September 2021).

35. Available online: https://www.mercosur.int/ (accessed on 1 September 2021).

36. Special issue "Health effects of agrochemicals as Endocrine Disruptors", Editorial. Mol. Cell. Endocrinol. 2020, 517, 110982. [CrossRef]

37. Wang, J. Analytical Electrochemistry, 3rd ed.; Wiley \& Sons: Hoboken, NJ, USA, 2006.

38. Cosnier, S. Electrochemical Biosensors. In Pan Stanford Series on the High-Tech of Biotechnology; Taylor \& Francis Group: Boca Raton, FL, USA, 2015.

39. Kalinowska, K.; Bystrzanowska, M.; Tobiszewski, M. Chemometrics approaches to green analytical chemistry procedure development. Curr. Opin. Green Sustain. Chem. 2021, 30, 100498. [CrossRef]

40. Eguílaz, M.; Gutierrez, A.; Gutierrez, F.; Gonzalez-Domínguez, J.M.; Ansón-Casaos, A.; Hernández-Ferrer, J.; Ferreyra, N.F.; Martínez, M.T.; Rivas, G. Covalent functionalization of single-walled carbon nanotubes with polytyrosine: Characterization and analytical applications for the sensitive quantification of polyphenols. Anal. Chim. Acta 2016, 909, 51-59. [CrossRef]

41. Gutiérrez, F.; Ortega, G.; Cabrera, J.L.; Rubianes, M.D.; Rivas, G.A. Quantification of Quercetin Using Glassy Carbon Electrodes Modified with Multiwalled Carbon Nanotubes Dispersed in Polyethylenimine and Polyacrylic Acid. Electroanalysis 2010, 22, 2650-2657. [CrossRef]

42. Tesio, A.Y.; Granero, A.M.; Vettorazzi, N.R.; Ferreyra, N.F.; Rivas, G.A.; Fernández, H.; Zon, M.A. Development of an electrochemical sensor for the determination of the flavonoid luteolin in peanut hull samples. Microchem. J. 2014, 115, 100-105. [CrossRef]

43. Tesio, A.Y.; Robledo, S.N.; Granero, A.M.; Fernández, H.; Zon, M.A. Simultaneous electroanalytical determination of luteolin and rutin using artificial neural networks. Sens. Actuators B Chem. 2014, 203, 655-662. [CrossRef]

44. Gomez, F.J.V.; Espino, M.; Fernandez, M.A.; Raba, J.; Silva, M.F. Enhanced electrochemical detection of quercetin by natural Deep Eutectic Solvents. Anal. Chim. Acta 2016, 936, 91-96. [CrossRef] [PubMed]

45. Tonello, N.; Moressi, M.B.; Robledo, S.N.; D’Eramo, F.; Marioli, J.M. Square wave voltammetry with multivariate calibration tools for determination of eugenol, carvacrol and thymol in honey. Talanta 2016, 158, 306-314. [CrossRef]

46. Robledo, S.N.; Pierini, G.D.; Diaz Nieto, C.H.; Fernández, H.; Zon, M.A. Development of an electrochemical method to determine phenolic monoterpenes in essential oils. Talanta 2019, 196, 362-369. [CrossRef]

47. Hoyos-Arbeláez, J.; Ramírez Garcí, G.; Arévalo, F.J.; Vázquez, M.; Fernández, H.; Gutiérrez Granados, S. Electrochemical determination of mangiferin using glassy carbon electrodes modified with carbonaceous nanomaterials. J. Electroanal. Chem. 2018, 808, 1-7. [CrossRef]

48. Pierini, G.D.; Foster, C.W.; Rowley-Neale, S.J.; Fernández, H.; Banks, C.E. A facile electrochemical intercalation and microwave assisted exfoliation methodology applied to screen-printed electrochemical-based sensing platforms to impart improved electroanalytical outputs. Analyst 2018, 143, 3360-3365. [CrossRef] 
49. Pierini, G.D.; Maccio, S.A.; Robledo, S.N.; Ferrari, A.G.-M.; Banks, C.E.; Fernández, H.; Zon, M.A. Screen-printed electrochemicalbased sensor for taxifolin determination in edible peanut oils. Microchem. J. 2020, 159, 105442. [CrossRef]

50. Robledo, S.N.; Zon, M.A.; Ceballos, C.D.; Fernández, H. Qualitative and quantitative electroanalysis of synthetic phenolic antioxidant mixtures in edible oils based on their acid-base properties. Food Chem. 2011, 127, 1361-1369. [CrossRef] [PubMed]

51. Robledo, S.N.; Tesio, A.Y.; Ceballos, C.D.; Zon, M.A.; Fernández, H. Electrochemical ultra-micro sensors for the determination of synthetic and natural antioxidants in edible vegetable oils. Sens. Actuators B Chem. 2014, 192, 467-473. [CrossRef]

52. Robledo, S.N.; Zachetti, V.G.L.; Zon, M.A.; Fernández, H. Quantitative determination of tocopherols in edible vegetable oils using electrochemical ultra-microsensors combined with chemometric tools. Talanta 2013, 116, 964-971. [CrossRef] [PubMed]

53. Pierini, G.D.; Bortolato, S.A.; Robledo, S.R.; Alcaraz, M.R.; Fernández, H.; Goicoechea, H.C.; Zon, M.A. Second-order electrochemical data generation to quantify carvacrol in oregano essential oils. Food Chem. 2022, 368, 130840. [CrossRef]

54. Gutiérrez, A.; Lozano, M.L.; Galicia, L.; Ferreyra, N.F.; Rivas, G.A. Electrochemical Sensing of Uric Acid Using Glassy Carbon Modified with Multiwall Carbon Nanotubes Dispersed in Polyethylenimine. Electroanalysis 2014, 26, 2191-2196. [CrossRef]

55. Tang, L.; Li, S.; Han, F.; Liu, L.; Xu, L.; Ma, W.; Kuang, H.; Li, A.; Wang, L.; Xu, C. SERS active Au@Ag nanorod dimers for ultrasensitive dopamine detection. Biosens. Bioelectron. 2015, 71, 7-12. [CrossRef]

56. Gutiérrez, A.; Gasnier, A.; Pedano, M.L.; Gonzalez-Dominguez, J.M.; Ansýn-Casaos, A.; Hernández-Ferrer, J.; Galicia, L.; Rubianes, M.D.; Martínez, M.T.; Rivas, G.A. Electrochemical Sensor for the Quantification of Dopamine Using Glassy Carbon Electrodes Modified with Single-Wall Carbon Nanotubes Covalently Functionalized with Polylysine. Electronalysis 2015, 27, 1565-1571. [CrossRef]

57. Granero, A.M.; Pierini, G.D.; Robledo, S.N.; Di Nezio, M.S.; Fernández, H.; Zon, M.A. Simultaneous determination of ascorbic and uric acids and dopamine in human serum samples using three-way calibration with data from square wave voltammetry. Microchem. J. 2016, 129, 205-212. [CrossRef]

58. Granero, A.M.; Fernández, H.; Agostini, E.; Zon, M.A. An amperometric biosensor based on peroxidases from Brassica napus for the determination of the total polyphenolic content in wine and tea samples. Talanta 2010, 83, 249-255. [CrossRef] [PubMed]

59. Mohtar, L.G.; Aranda, P.; Messina, G.A.; Nazareno, M.A.; Pereira, S.V.; Raba, J.; Bertolino, F.A. Amperometric biosensor based on laccase immobilized onto a nanostructured screen-printed electrode for determination of polyphenols in propolis. Microchem. J. 2019, 144, 13-18. [CrossRef]

60. Lopez, J.C.; Zon, M.A.; Fernández, H.; Granero, A.M. Development of an enzymatic biosensor to determine eugenol in dental samples. Talanta 2020, 210, 120647. [CrossRef]

61. da Rocha Ferreira, F.; Gomes da Silva, E.; Méndez De Leo, L.P.; Calvo, E.J.; de Souza Bento, E.; Fonseca Goulart, M.O.; Caxico de Abreu, F. Electrochemical investigations into host-guest interactions of a natural antioxidant compound with $\beta$-cyclodextrin. Electrochim. Acta 2010, 56, 797-803. [CrossRef]

62. Langmaier, J.; Garay, F.; Kivlehan, F.; Chaum, E.; Lindner, E. Electrochemical quantification of 2,6-diisopropylphenol (propofol). Anal. Chim. Acta 2011, 704, 63-67. [CrossRef]

63. Dalmasso, P.R.; Pedano, M.L.; Rivas, G.A. Electrochemical determination of ascorbic acid and paracetamol in pharmaceutical formulations using a glassy carbon electrode modified with multi-wall carbon nanotubes dispersed in polyhistidine. Sens. Actuators B Chem. 2012, 173, 732-736. [CrossRef]

64. Gutierrez, F.; Comba, F.N.; Gasnier, A.; Gutierrez, A.; Galicia, L.; Parrado, C.; Rubianes, M.D.; Rivas, G.A. Graphene Paste Electrode: Analytical Applications for the Quantification of Dopamine, Phenolic Compounds and Ethanol. Electroanalysis 2014, 26, 1694-1701. [CrossRef]

65. Costa, D.J.E.; Martinez, A.M.; Ribeiro, W.F.; Bichinho, K.M.; Di Nezio, M.S.; Pistonesi, M.F.; Araujo, M.C.U. Determination of tryptamine in foods using square wave adsorptive stripping voltammetry. Talanta 2016, 154, 134-140. [CrossRef] [PubMed]

66. Pierini, G.D.; Robledo, S.N.; Zon, M.A.; Di Nezio, M.S.; Granero, A.M.; Fernández, H. Development of an electroanalytical method to control quality in fish samples based on an edge plane pyrolytic graphite electrode. Simultaneous determination of hypoxanthine, xanthine and uric acid. Microchem. J. 2018, 138, 58-64. [CrossRef]

67. Perrotta, P.R.; Vettorazzi, N.R.; Arévalo, F.J.; Granero, M.A.; Chulze, S.N.; Zon, M.A.; Fernández, H. Electrochemical studies of Ochratoxin A mycotoxin at gold electrodes modified with cysteamine self-assembled monolayers. Its ultrasensitive quantification in red wine samples. Electroanalysis 2011, 23, 1585-1592. [CrossRef]

68. Visconti, A.; Pascale, M.; Centonze, G. Determination of Ochratoxin A in Wine and Beer by Immunoaffinity Column Cleanup and Liquid Chromatographic Analysis with Fluorometric Detection: Collaborative Study. J. AOAC Int. 2001, 84, 1818-1827. [CrossRef] [PubMed]

69. Fernández-Baldo, M.A.; Bertolino, F.A.; Fernández, G.; Messina, G.A.; Sanz, M.I.; Raba, J. Determination of Ochratoxin A in apples contaminated with Aspergillus ochraceus by using a microfluidic competitive immunosensor with magnetic nanoparticles. Analyst 2011, 136, 2756-2762. [CrossRef]

70. Jestoi, M. Emergin Fusarium-mycotoxins fusaproliferin, beauvericin, enniatins, and moniliform: A review. Crit. Food Rev. Sci. Nutr. 2008, 48, 21-49. [CrossRef]

71. Díaz Toro, P.C.; Arévalo, F.J.; Zon, M.A.; Fernández, H. Studies of the electrochemical behavior of moniliformin mycotoxin and its sensitive determination at pretreated glassy carbon electrodes in a non-aqueous médium. J. Electroanal. Chem. 2015, 738, 40-46. [CrossRef] 
72. Díaz Toro, P.C.; Arévalo, F.J.; Fumero, M.V.; Zon, M.A.; Fernández, H. Very sensitive electrochemical sensor for moniliformin detection in maize samples. Sens. Actuators B Chem. 2016, 225, 384-390. [CrossRef]

73. Vaclavikova, M.; Dzuman, Z.; Lacina, O.; Fenclova, M.; Veprikova, Z.; Zachariasova, M.; Hajslova, J. Monitoring survey of patulin in a variety of fruit-based products using a sensitive UHPLC-MS/MS analytical procedure. Food Control 2015, 47, 577-584. [CrossRef]

74. Li, X.; Peng, X.; Wang, Q.; Zuo, H.; Meng, X.; Liu, B. Effective detoxification of patulin from aqueous solutions by immobilized porcine pancreatic lipase. Food Control 2017, 78, 48-56. [CrossRef]

75. Chanique, G.D.; Arévalo, A.H.; Zon, M.A.; Fernández, H. Eletrochemical reduction of patulin and 5-hydroxymethylfurfural in both neutral and acid non-aqueous media. Their electroanalytical determination in apple juices. Talanta 2013, 111, 85-92. [CrossRef]

76. Zachetti, V.G.L.; Granero, A.M.; Zón, M.A.; Fernández, H. Development of an amperometric biosensor based on peroxidases to quantify citrinin in rice samples. Bioelectrochemistry 2013, 91, 37-43. [CrossRef] [PubMed]

77. Díaz Nieto, C.H.; Granero, A.M.; Garcia, D.; Nesci, A.; Barros, G.; Zon, M.A.; Fernández, H. Development of a third-generation biosensor to determine sterigmatocystin mycotoxin: An early warning system to detect aflatoxin B1. Talanta 2019, 194, 253-258. [CrossRef]

78. Fernández-Baldo, M.; Bertolino, F.A.; Messina, G.A.; Sanz, M.I.; Raba, J. Modified magnetic nanoparticles in an electrochemical method for the ochratoxin A determination in Vitis vinifera red grapes tissues. Talanta 2010, 83, 651-657. [CrossRef] [PubMed]

79. Panini, N.V.; Bertolino, F.A.; Salinas, E.; Messina, G.A.; Raba, J. Zearalenone determination in corn silage samples using an immunosensor in a continuous-flow/stopped-flow systems. Biochem. Eng. J. 2010, 51, 7-13. [CrossRef]

80. Panini, N.V.; Salinas, E.; Messina, G.A.; Raba, J. Modified paramagnetic beads in a microfluidic system for the determination of zearalenone in feedstuffs samples. Food Chem. 2011, 2, 791-796. [CrossRef]

81. Riberi, W.I.; Tarditto, L.V.; Zon, M.A.; Arévalo, F.J.; Fernández, H. Development of an electrochemical immunosensor to determine zearalenone in maize using carbon screen printed electrodes modified with multi-walled carbon nanotubes/polyethyleneimine dispersions. Sens. Actuators B Chem. 2018, 254, 1271-1277. [CrossRef]

82. Regiart, M.; Fernández, O.; Vicario, A.; Villarroel-Rocha, J.; Sapag, K.; Messina, G.A.; Raba, J.; Bertolino, F.A. Mesoporous immunosensor applied to zearalenone determination in Amaranthus cruentus sedes. Microchem. J. 2018, 141, 388-394. [CrossRef]

83. Arévalo, F.J.; Granero, A.M.; Fernández, H.; Raba, J.; Zon, M.A. Citrinin (CIT) determination in rice samples using a microfluidic electrochemical immunosensor. Talanta 2011, 83, 966-973. [CrossRef]

84. Regiart, M.; Pereira, S.V.; Spotorno, V.G.; Bertolino, F.A.; Raba, J. Food safety control of zeranol through voltammetric immunosensing on Au-Pt bimetallic nanoparticle surfaces. Analyst 2014, 139, 4702-4709. [CrossRef]

85. Regiart, M.; Seia, M.A.; Messina, G.A.; Bertolino, F.A.; Raba, J. Electrochemical immunosensing using a nanostructured functional platform for determination of $\alpha$-zearalanol. Microchim. Acta 2015, 182, 531-538. [CrossRef]

86. Arévalo, F.J.; González-Techera, A.; Zon, M.A.; González-Sapienza, G.; Fernández, H. Ultra-sensitive electrochemical immunosensor using analyte peptidomimetics selected from phage display peptide libraries. Biosens. Bioelectron. 2012, 32, 231-237. [CrossRef]

87. Di Tocco, A.; Porcal, G.V.; Zon, M.A.; Fernández, H.; Robledo, S.N.; Arévalo, F.J. Inmunosensor electroquímico para la detección del herbicida molinato usando fagos conjugados con puntos cuánticos de CdS. In Proceedings of the X Congreso Argentino de Química Analítica, La Pampa, Argentina, 17 September 2019. (In Spanish).

88. González-Techera, A.; Zon, M.A.; Molina, P.G.; Fernández, H.; González-Sapienza, G.; Arévalo, F.J. Development of a highly sensitive noncompetitive electrochemical immunosensor for the determination of atrazine by phage anti-immunocomplex assay. Biosens. Bioelectron. 2015, 64, 650-656. [CrossRef] [PubMed]

89. Bia, G.; Borgnino, L.; Ortiz, P.I.; Pfaffen, V. Multivariate optimization of square wave voltammetry using bismuth film electrode to determine atrazine. Sens. Actuators B Chem. 2014, 203, 396-405. [CrossRef]

90. Betancourth, J.M.; Cuellar, M.; Ortiz, P.I.; Pfaffen, V. Multivariate cathodic square wave stripping voltammetry optimization for nitro group compounds determination using antimony film electrodes. Microchem. J. 2018, 139, 139-149. [CrossRef]

91. Krepper, G.; Pistonesi, M.F.; Di Nezio, M.S. Adsorptive square wave voltammetric determination of amitraz in Argentine honeys with a microwave-assisted sample treatment. Microchem. J. 2019, 150, 104068. [CrossRef]

92. Ghanbari, K.; Roshani, M.; Goicoechea, H.C.; Jlalvand, A.R. Developing an elegant and integrated electrochemical-theoretical approach for detection of DNA damage induced by 4-nonylphenol. Heliyon 2019, 5, e02755. [CrossRef] [PubMed]

93. Regiart, M.; Fernández-Baldo, M.A.; Navarro, P.; Pereira, S.V.; Raba, J.; Messina, G.A. Nanostructured electrode using CMK8/CuNPs platform for herbicide detection in environmental samples. Microchem. J. 2020, 157, 105014. [CrossRef]

94. Kergaravat, S.V.; Fabiano, S.N.; Soutullo, A.R.; Hernández, S.R. Comparison of the performance analytical of two glyphosate electrochemical screening methods based on peroxidase enzyme inhibition. Microchem. J. 2021, 160, 105654. [CrossRef] 